\title{
Screening and identification of desulfurization microorganisms
}

\author{
Junjiao Zhang ${ }^{1, *}$, Wenjing $L i^{2, *}$ \\ ${ }^{1}$ Qilu institute of technology, 250200 Jinan, China \\ ${ }^{2}$ Shandong Institute of Commerce and Technology, 250200 Jinan, China
}

\begin{abstract}
In recent years, biological desulfurization technology has attracted more and more attention from domestic and foreign researchers due to its mild reaction conditions, high efficiency, and environmental protection. In this study, bacteria were collected from oil depots, sewage treatment plants and sewage, and using a screening medium with DBT as the only sulfur source. Three strains that can degrade DBT were isolated, numbered 1, 2, and 3. Through the identification of morphological characteristics, physiological and biochemical identification and molecular identification, it is preliminarily determined that the bacteria No. 1 belongs to the genus Kinetococcus, the bacteria No. 2 is Micrococcus mutans, the bacteria No. 3 is Micrococcus luteus, and the desulfurization capacity of the three bacteria is No. 3. Bacteria $>$ Bacteria No.1 > Bacteria No.2.
\end{abstract}

\section{Introduction}

During the processing and utilization of coal and petroleum, harmful substances such as sulfur oxides will be discharged into the surrounding environment in various ways, which results in air pollution, acid rain, greenhouse effect, and destruction of the ozone layer ${ }^{[1]}$. The pre-combustion biological desulfurization of coal and oil is carried out at room temperature and pressure. It is a potential clean technology with many advantages of safety and environmental protection, low investment, low consumption and high efficiency at this stage ${ }^{[2,3]}$. However, due to the instability of microbial desulfurization gene expression, there are problems such as easy variation during the growth of desulfurization microorganisms and complicated desulfurization process mechanism. At present, using microbial desulfurization is still in the laboratory research stage. Screening stable and efficient desulfurization microorganisms by effective experimental methods is the focus of current $\operatorname{research}^{[4,5]}$.

Coal and petroleum contain a large amount of extremely difficult-to-degrade and heterocyclic form organic sulfur. Dibenzothiophene (DBT) is one of the representative species. Using DBT as a model compound to carry out research on organic sulfur removing have been achieved. In this study, samples were taken from oil depots, sewage treatment plants, and sewage. The screening medium with DBT as the sole sulfur source was used to screen desulfurization microorganisms, and the morphological, physiological and biochemical characteristics were identifiel. Molecular identification of $16 \mathrm{SrDNA}$ was conducted. Finally, three microorganis- mms with desulfurization ability were screened out for future research.

\section{Materials and methods}

\subsection{Materials and reagents}

\subsubsection{Medium}

(1) Screening medium: $\mathrm{K}_{2} \mathrm{HPO}_{4} \cdot 3 \mathrm{H}_{2} \mathrm{O} \quad 4 \mathrm{~g}$, $\mathrm{NaH}_{2} \mathrm{PO}_{4} \cdot 2 \mathrm{H}_{2} \mathrm{O} \quad 4 \mathrm{~g}, \quad \mathrm{NH}_{4} \mathrm{Cl} \quad 2 \mathrm{~g}, \quad \mathrm{MgCl}_{2} \cdot 6 \mathrm{H}_{2} \mathrm{O} \quad 0.2 \mathrm{~g}$, $\mathrm{CaCl}_{2} \cdot 2 \mathrm{H}_{2} \mathrm{O} 0.001 \mathrm{~g}, \mathrm{FeCl}_{3} \cdot 6 \mathrm{H}_{2} \mathrm{O} 0.001 \mathrm{~g}$, glycerol $2 \mathrm{~g}$, distilled water $1000 \mathrm{~mL}$, DBT concentration changes with the progress of the experiment.

(2) Beef extract peptone medium: beef extract $5.0 \mathrm{~g}$, peptone $10.0 \mathrm{~g}, \mathrm{NaCl} 5.0 \mathrm{~g}$, water $1000 \mathrm{~mL}, \mathrm{pH} 7.2 \sim 7.4$.

(3) Sugar fermentation medium: peptone $2 \mathrm{~g}$, glucose $10 \mathrm{~g}, \mathrm{~K}_{2} \mathrm{HPO}_{4} 0.2 \mathrm{~g}, \mathrm{NaCl} 5.0 \mathrm{~g}$, bromothymol blue $1 \%$ aqueous solution $3 \mathrm{~mL}$, distilled water $1000 \mathrm{~mL}, \mathrm{pH}$ 7.0 7.2.

(4) Nitrogen-free medium (Axube medium): glucose $10.0 \mathrm{~g}$, potassium dihydrogen phosphate $0.2 \mathrm{~g}$, magnesium sulfate $0.2 \mathrm{~g}$, sodium chloride $0.2 \mathrm{~g}$, calcium sulfate $0.1 \mathrm{~g}$, calcium carbonate $5.0 \mathrm{~g}$, distilled water $1000 \mathrm{~mL}, \mathrm{pH} 7.0$.

(5) Glucose peptone medium (methyl red experiment): Peptone $5.0 \mathrm{~g}$, glucose $5.0 \mathrm{~g}, \mathrm{NaCl} 5.0 \mathrm{~g}$, distilled water $1000 \mathrm{~mL}, \mathrm{pH} 7.0 \sim 7.2$.

(6) Experimental medium for producing hydrogen sulfide: peptone $10.0 \mathrm{~g}, \mathrm{NaCl} 5.0 \mathrm{~g}$, beef extract $10.0 \mathrm{~g}$, cysteine $0.5 \mathrm{~g}$, distilled water $1000 \mathrm{~mL}, \mathrm{pH} 7.0 \sim 7.4$.

(7) Gelatin liquefaction medium: peptone $5.0 \mathrm{~g}$, gelatin 100 150g, distilled water $1000 \mathrm{~mL}, \mathrm{pH}$ 7.2 7.4.

\footnotetext{
* Corresponding author: 382349198@qq.com; 749813130@qq.com
} 


\subsubsection{Experimental method}

(1) Sample collection and processing

Three samples collection locations were selected: the oilsoaked soil in the Huangdao Oil Depot, the sewage from the sewage treatment plant, and the sewage at the school gate. The three kinds of bacteria obtained were named number 1,2 , and 3 .

The inoculation amount of enriched culture bacteria was shown in table 1 .

Table 1 Inoculation of enriched culture bacteria

\begin{tabular}{ccc}
\hline Sample bacteria & Medium amount $/ \mathrm{ml}$ & Inoculation amount \\
\hline number 1 & 210 & $10 \mathrm{~mL}$ \\
number 2 & 210 & $10 \mathrm{~mL}$ \\
number 3 & 210 & $10 \mathrm{~mL}$ \\
\hline
\end{tabular}

(2) Desulfurization bacteria screening

The solid medium with DBT concentration of $1 \mathrm{mmol} / \mathrm{L}, 2 \mathrm{mmol} / \mathrm{L}, \quad 5 \mathrm{mmol} / \mathrm{L}, \quad 6 \mathrm{mmol} / \mathrm{L}, \quad 7 \mathrm{mmol} / \mathrm{L}$, $8 \mathrm{mmol} / \mathrm{L}$ and $9 \mathrm{mmol} / \mathrm{L}$ were prepared respectively. The bacterial culture of No.1, No.2 and No.3 were diluted to $10^{-6}$ and coated to the medium of the corresponding concentration of DBT concentration. The bacteria were cultured at $30^{\circ} \mathrm{C}, 270 \mathrm{r} / \mathrm{min}$ on a shaker for 3 days. The culture results of three strains growth in DBT medium with different concentrations were observed and counted.

(3) Identification of desulfurization microorganisms

1) Cell morphology observation

Cell morphology identification was conducted by microscope observation.

2) Molecular biology identification

The genetic attributes were determined by 16SrDNA.

\section{Results}

\subsection{The growth of bacterias at different DBT concentrations}

When screening bacteria with different concentration of DBT, the growth of different bacterias were shown in table 2 below.

Table 2 The growth of bacterias No.1, No.2 and No.3

\begin{tabular}{cccc}
\hline $\begin{array}{c}\text { DBT } \\
\text { concentration } \\
(\mathrm{mmol} / \mathrm{L})\end{array}$ & $\begin{array}{c}\text { Colony } \\
\text { Number of } \\
\text { No.1 } \\
\text { bacteria }\end{array}$ & $\begin{array}{c}\text { Colony } \\
\text { Number of } \\
\text { No.2 bacteria }\end{array}$ & $\begin{array}{c}\text { Colony } \\
\text { Number of } \\
\text { No.3 } \\
\text { bacteria }\end{array}$ \\
\hline 1 & Uncountable & Uncountable & Uncountable \\
2 & Uncountable & Uncountable & Uncountable \\
5 & 100 & 100 & Uncountable \\
6 & 80 & 60 & 100 \\
7 & 30 & 0 & 50 \\
8 & 4 & 0 & 30 \\
9 & 0 & 0 & 12 \\
\hline
\end{tabular}

According to the growth of the bacteria at different DBT concentrations, it could be concluded that bacteria No.1 could tolerance a maximum DBT concentration of $8 \mathrm{mmol} / \mathrm{L}$. Bacteria No.2 could grow in a screening medium with a DBT concentration of $6 \mathrm{mmol} / \mathrm{L}$. Bacteria No.3 could grow at the selection medium with the highest DBT concentration of $9 \mathrm{mmol} / \mathrm{L}$. It was preliminarily judged that the desulfurization capacity of the three bacteria was No. $3>$ No. $1>$ No. 2 .

\subsection{Morphological characteristics and physiological and biochemical identification of desulphurization bacteria}

\subsubsection{Observation of colony morphology}

The colony morphology of three bacterias were shown in table 3 and fig. 1.

Table 3 The colony morphology of three bacterias

\begin{tabular}{cc}
\hline Bacteria & Colony morphology \\
\hline Bacteria No. 1 & Round, milky white, opaque, protruding surface, moist, easy to pick up, diameter \\
& \\
Bacteria No. 2 & Round, milky white, opaque, protruding surface, moist, easy to pick up, diameter \\
& $0.3 \mathrm{~cm} \sim 0.8 \mathrm{~cm}$
\end{tabular}




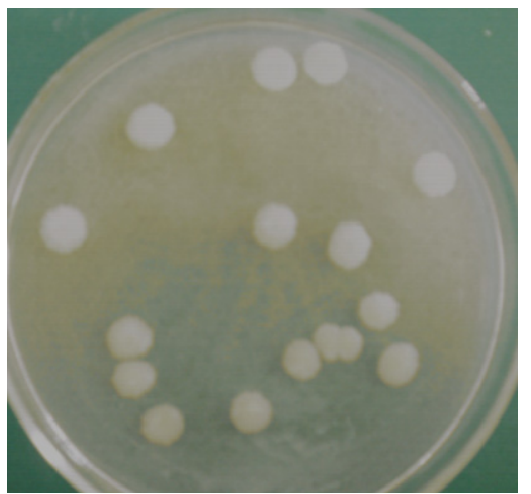

Fig. 1 The colony morphology of desulfurization bacteria

\subsubsection{The physiological and biochemical identification}

The results of physiological and biochemical identification of three bacterias were shown in table 4 .

Table 4 Physiological and biochemical identification results

\begin{tabular}{|c|c|c|c|c|c|c|c|}
\hline Bacteria & $\begin{array}{l}\text { Gram } \\
\text { staining }\end{array}$ & Aerobic test & $\begin{array}{l}\text { Methyl } \\
\text { red test }\end{array}$ & $\begin{array}{c}\text { Starch hydrolysis } \\
\text { test }\end{array}$ & $\begin{array}{c}\text { Gelatin } \\
\text { liquefaction } \\
\text { test } \\
\end{array}$ & $\begin{array}{c}\text { Sugar } \\
\text { fermentation } \\
\text { test } \\
\end{array}$ & $\begin{array}{l}\text { Hydrogen sulfide } \\
\text { production test }\end{array}$ \\
\hline No.1 & Purple & $\begin{array}{l}\text { Bacteria grow at the } \\
\text { puncture site }\end{array}$ & Yellow & $\begin{array}{c}\text { Transparent circle, } \\
\Phi 1.6 \mathrm{~cm}\end{array}$ & $\begin{array}{l}\text { Gelatin is } \\
\text { liquefied }\end{array}$ & $\begin{array}{l}\text { No acid, no } \\
\text { bubbles }\end{array}$ & $\begin{array}{l}\text { Hydrogen sulfide } \\
\text { production }\end{array}$ \\
\hline No.2 & Purple & $\begin{array}{l}\text { Bacteria grow at the } \\
\text { puncture site }\end{array}$ & Yellow & $\begin{array}{c}\text { Transparent circle, } \\
\Phi 1.6 \mathrm{~cm}\end{array}$ & $\begin{array}{l}\text { Gelatin is } \\
\text { liquefied }\end{array}$ & Few bubbles & $\begin{array}{l}\text { Hydrogen sulfide } \\
\text { production }\end{array}$ \\
\hline No.3 & Purple & $\begin{array}{l}\text { Sterile growth at the } \\
\text { puncture site, bacteria } \\
\text { growth on the surface } \\
\text { of the medium }\end{array}$ & Yellow & $\begin{array}{l}\text { No transparent } \\
\text { circle }\end{array}$ & $\begin{array}{c}\text { Gelatin is } \\
\text { not } \\
\text { liquefied }\end{array}$ & Few bubbles & $\begin{array}{l}\text { Hydrogen sulfide } \\
\text { production }\end{array}$ \\
\hline
\end{tabular}

\subsection{Molecular biology identification}

The molecular biology identification were performed by 16SrDNA identification, and the PCR amplification results of random primers were shown below. The gel image of S119 PCR amplification system was as follows.

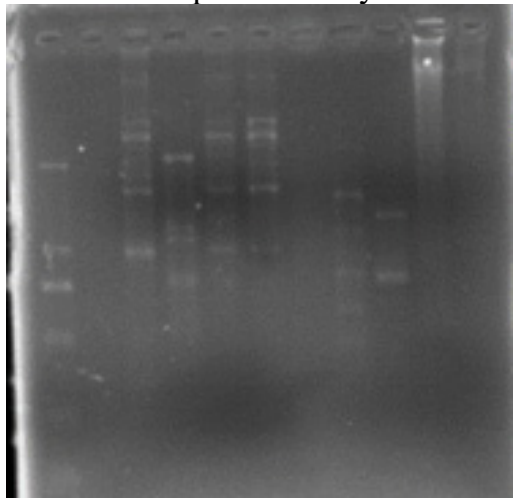

Fig. 2 Gel image of S119 PCR amplification system

The RAPD phylogenetic tree of S119 primer was obtained by cluster analysis with NTSYS-pc software as shown in fig. 3 .

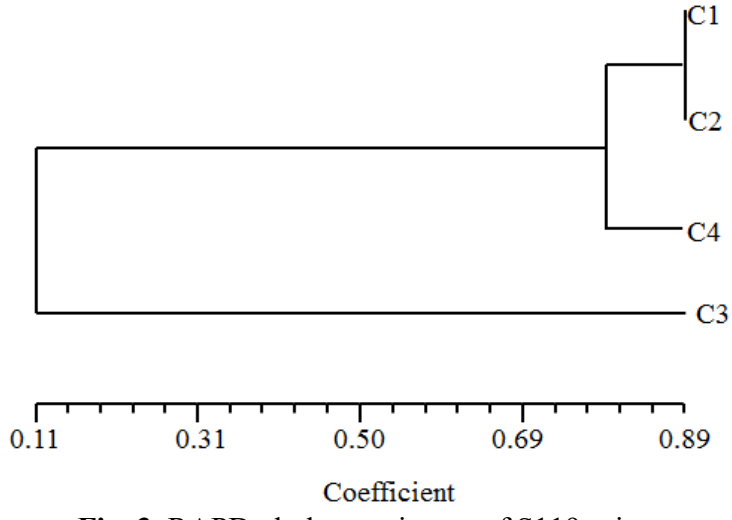

Fig. 3 RAPD phylogenetic tree of S119 primer

\section{Discussion}

As shown in the above figures, the genetic relationship between No.1 and No.3 bacteria was relatively close.

\subsection{Identification results and analysis of No. 1 bacteria}

The characteristics of the screened strain No.1 were as follows: the colonies were round, opaque, and protruding on the surface. The early colonies were milky white, and the front and back sides had the same color. Observed by staining, the cells were round, spherical, single or stacked in pairs or multiple irregularly, with an average size of $0.5-1.0 \mu \mathrm{m}$. Observed by gram staining, the 
bacterial cells were purple and positive. During the puncture culture, bacteria grew inside and on the surface of the medium, which were facultative aerobic bacteria. It had the ability to fix nitrogen and could hydrolyze starch but could not decompose cellulose. Fermentation of glucose did not produce acid or gas. Producing catalase. Hydrolyzing gelatin. Producing hydrogen sulfide.

Refer to "Berger's Bacteria Identification Manual", No.1 bacteria belonged to part fourteen (Gram-positive cocci), part a (aerobic and facultative anaerobic cocci), family I (micrococcus), kinesococcus genus.

\subsection{Identification results and analysis of No.2 bacteria}

The characteristics of the No. 2 strain were as follows: the colonies were round, opaque, and the surface was protruding. The early colonies were milky white, and the later colonies became yellow, moist, easy to provoke, and the front and back were the same color. Observed by staining, the cells were round, spherical, single or stacked in pairs or multiple irregularly, with an average size of $0.5-1.0 \mu \mathrm{m}$. Observed by gram staining, the bacterial cells were purple and positive. During puncture culture, bacteria grew inside the medium, which was a facultative aerobic bacteria. No nitrogen fixation ability. It could hydrolyze starch but could not decompose cellulose. Fermentation of glucose did not produce acid and gas. Producing catalase, and could hydrolyze gelatin. Producing hydrogen sulfide.

Refer to "Berger's Bacterial Identification Manual", No.2 bacteria belonged to the fourteenth part (Grampositive cocci), part a (atrophic and facultative anaerobic cocci), family I (micrococcaceae), genus I ( micrococcus), micrococcus mutans.

\subsection{Identification results and analysis of bacteria No. 3}

The characteristics of the No. 3 strain were as follows: the colonies were round, opaque, and protruding on the surface. The early colonies were milky white, and the later colonies became yellow, moist, easy to provoke, and the front and back sides had the same color. Observed by staining, the cells were round, spherical, single or stacked in pairs or multiple irregularly, with an average size of $0.5-1.0 \mu \mathrm{m}$. Observed by gram staining, the bacterial cells were purple and positive. During the puncture culture, there was no spreading growth in the punctured place, which was aerobic bacteria. It could not fix nitrogen, hydrolyze starch, decompose cellulose and use glucose as a carbon source. It could produce catalase, protease that could decompose gelatin and hydrogen sulfide. It did not produce acid and gas with glucose as the carbon source.

Refer to "Berger's Bacteria Identification Manual", No. 3 bacteria belonged to the fourteenth part (grampositive coccus), part a (atrophic and facultative anaerobic coccus), family I (micrococcaceae), genus I (micrococcus), micrococcus luteus.

\section{Conclusion}

Using DBT as the only sulfur source, three bacterias named bacteria No.1, No.2 and No.3 were screened out. By bacteria morphology observation, physiological and biochemical characteristics analyzation and molecular identification experiments, it was preliminarily determined that No.1 bacteria belonged to the genus Kinetococcus, No.2 was Micrococcus mutans, and No.3 was Micrococcus luteus. The desulfurization capacity of the three strains was preliminarily determined to be No. 3 bacteria $>$ No. 1 bacteria $>$ No. 2 bacteria.

\section{References}

1. Chauhan A K, Ahmad A, Singh S P, et al. Int Biodeter Biodegr. 104, 105-111 (2015).

2. Gonsalvesh L, Marinov S P, Stefanova M, et al. Fuel. 87, 2533-2543 (2008).

3. Guerinik K, Al-Mutawah Q. World J Microb Biot. 19, 941-945 (2003).

4. Baeza J A, Gabriel D, Lafuente J. Process Biochem. 39, 1615-1624 (2004).

5. Ahn Y H. Process Biochem. 41, 1709-1721 (2006). 